\title{
Penggunaan Media Audio Visual dalam Meningkatkan Kemampuan Membaca Alquran
}

\author{
Mhd. Ricky Fadil Sihombing 1 , Alfurqan ${ }^{2}$ \\ rizkyfadilsihombing@gmail.com ${ }^{1}$, alfurqan@fis.unp.ac.id ${ }^{2}$ \\ Universitas Negeri Padang ${ }^{1,2}$
}

\begin{tabular}{l}
\hline ARTICLE INFO \\
\hline Article history: \\
Received, 21 October 2021 \\
Revised, 09 November \\
2021 \\
Accepted, 30 November \\
2021 \\
\hline Keywords: \\
Penggunaan Media \\
Pembelajaran, Audio \\
Visual, Peningkatan \\
Kemampuan, Membaca \\
Alquran
\end{tabular}

Clonflict of Interest:

None

Funding:

None
ABSTRACT VI belum mencapai KKM 75 dilihat dari nilai ulangan siswa yang lulus yaitu sebanyak 7 siswa dan yang tidak lulus sebanyak 15 siswa pada penggunaan media audio visual sebagai alat pendukung dalam meningkatkan kemampuan membaca Alquran. Penelitian ini bertujuan untuk mengetahui penggunaan media pembelajaran audio visual dalam meningkatkan kemampuan membaca Alquran di SDN 153028 Padang Masiang 1 Barus. Metode penelitian ini menggunakan metode Kualitatif dengan pendekatan Deskriptif. Informan penelitian berjumlah 22 siswa kelas IV, V dan VI. Teknik penelitian menggunakan teknik Purposive Sampling. Hasil penelitian menunjukkan siswa kelas IV, V dan VI telah mengalami peningkatan dilihat dari kategori tajwid, makharijul huruf dan fasoha dalam membaca Alquran, nilai ulangan siswa meningkat atau lulus KKM 75 berjumlah 16 siswa dan 6 siswa tidak lulus. Penulis menyimpulkan penggunaan media audio visual dalam meningkatkan kemampuan membaca Alquran di SDN 153028 Padang Masiang 1 Barus terlaksana dengan baik dan mengalami peningkatan yang signifikan.

Corresponding Author: Mhd. Ricky Fadil Sihombing, Department Islamic Education Faculty of Social Science Universitas Negeri Padang, Indonesia, Email: rizkyfadilsihombing@gmail.com Phone: $+6281360122331$

\begin{tabular}{l|cc|l}
\hline & C) & $\underset{\mathrm{EY}}{()}$ & Copyright $C 2021$, Author(s) \\
\hline
\end{tabular}

\section{Pendahuluan}

Alquran menurut bahasa adalah baca atau bacaan yang wajib di baca dan dipelajari oleh setiap muslim. Menurut istilah, ulama berbeda pendapat dalam memberikan definisi terhadap Alquran diantaranya kalam Allah yang merupakan mu'jizat diturunkan kepada Nabi Muhammad SAW melalui perantara malaikat Jibril dengan lafal dan maknanya dari Allah SWT, yang diturunkan secara mutawatir; membacanya merupakan ibadah; dimulai surah AlFatihah dan diakhiri dengan surah An-Nas (Shihab, 2008).

Keberhasilan suatu pembelajaran memerlukan beberapa komponen belajar, Suyanto dan Djihad Hisyam 2018 menyebutkan "Komponen dalam pembelajaran mampu membentuk sistem yang saling terkait, sehingga menciptakan proses pembelajaran yang berkualitas. Komponen tersebut di antaranya yaitu tujuan pembelajaran, materi, metode, media, guru, siswa, penilaian/evaluasi" (Suyanto dan Djihad Hisyam, 2010:81). 
Mhd. Ricky Fadil Sihombing dan Alfurqan: Penggunaan Media Audio Visual dalam...

Selanjutnya Arsyad 2013 mengemukakan bahwa pemilihan media yang sesuai dengan materi akan memudahkan guru dalam mengatasi masalah siswa yang sulit memahami materi pembelajaran. Pemilihan media yang tepat menghasilkan pengalaman belajar siswa secara mendalam dan cepat memahami pelajaran tersebut ketika belajar Alquran dengan menggunakan media pembelajaran (Arsyad, 2013).

Penggunaan media pembelajaran audio visual pada materi Alquran akan mendukung proses kegiatan pembelajaran tersebut. Guru berperan sebagai motivator dan fasilitator pada mata pelajaran Pendidikan Agama Islam Materi Alquran ditingkat SD/MI Sederajat. Media audio visual efektif digunakan yaitu media ini akan menampilkan gambar dan suara yang mempermudah siswa memahami materi Alquran yang disampaikan guru (Rahmawati, 2014).

Menurut data Referensi Kepala Dinas Pendidikan Kabupaten Tapanuli Tengah tahun 2021 diketahui 14 SDN serta 4 SD Swasta di Kec. Barus salah satunya adalah SDN 153028 Padang Masiang 1 Barus yang menjadi lokasi penelitian penulis. Penulis memilih SDN 153028 Padang Masiang 1 Barus karena fasilitas belajar sudah menggunakan media pembelajaran audio visual pada mata pelajaran Pendidikan Agama Islam materi Alquran.Sebelumnya guru PAI tidak menggunakan media pembelajaran audio visual, kondisi siswa belum mampu membaca Alquran dengan baik. Namun setelah guru menggunakan media audio visual pada mata pelajaran Pendidikan Agama Islam materi Alquran, kondisi siswa sudah ada peningkatan dalam membaca Alquran.

Penulis melaksanakan observasi awal pada hari selasa tanggal 10 November 2020 dengan guru PAI Ibu Badria Marpaung, S.Pd. di SDN 153028 Padang Masiang 1 Barus Kabupaten Tapanuli Tengah, guru tersebut memberikan keterangan kepada penulis bahwa pada semester genap tahun 2020 sebahagian siswa kelas IV, V dan VI belum mampu membaca Alquran dengan baik karena guru tidak menggunakan media pembelajaran dalam proses pembelajran materi Alquran. Pada awal semester ganjil tahun 2021 guru sudah menggunakan media pembelajaran salah satunya media audio visual yang digunakan dalam pembelajaran PAI materi Alquran.

Berdasarkan paparan masalah diatas, penulis menemukan masalah siswa kelas IV, V dan VI yang belum mampu membaca Alquran dengan baik. Kategori mampu dalam membaca Alquran dengan baik adalah menguasai tajwid, huruf dan fasoha kelancaran membaca Alquran, sementara siswa kelas IV, V dan VI masih belum mampu menguasai kategori tersebut karena guru belum menggunakan media audio visual. Selanjutnya setelah guru sudah menggunakan media pembelajaran audio visual pada materi Alquran, siswa kelas IV, $\mathrm{V}$ dan VI sudah ada peningkatan dalam membaca Alquran.

Tujuan penelitian ini adalah: (1) Untuk mengetahui penggunaan media pembelajaran audio visual dalam meningkatkan kemampuan membaca Alquran di SDN 153028 Padang Masiang 1 Barus Kabupaten Tapanuli Tengah. (2) Mengetahui apa faktor-faktor pendukung dan penghambat dari penggunaan media pembelajaran audio visual pada materi Alquran. (3) Mengetahui hasil dari penggunaan media pembelajaran audio visual pada materi Alquran.

\section{Tinjauan Pustaka}

\section{a. Kemampuan Membaca Alquran}

Kemampuan membaca Alquran adalah kecakapan yang telah dilaksanakan siswa dalam membaca Alquran melalui tiga kriteria utama yaitu: makhraj, tajwid, dan kelancaran bacaan (Syaifullah, 2017). Kemudian kemampuan membaca Alquran merupakan kunci dasar yang harus dimiliki setiap muslim, karena hal utama dari pelaksanaan ibadah setiap muslim adalah mampu dalam membaca dan melantunkan ayat-ayat Alquran, dan ketika seorang muslim tidak mampu untuk membaca Alquran maka akan menjadi penghalang dalam melaksanakan ibadah (Rama Joni, Abdul Rahman, 2020). Berdasarkan pengertian kemampuan membaca Alquran diatas dapat dipahami bahwa kemampuan membaca Alquran merupakan hal yang wajib dimiliki setiap umat muslim. 


\section{b. Media Audio Visual}

Media audio visual merupakan media yang terdiri antara audio dan visual yang digabungkan dengan kaset audio yang memiliki unsur suara dan gambar yang biasa dilihat, contohnya rekaman video, berbagai ukuran film, slide suara dan sebagainya (Hastuti and Budianti, 2014).

Selanjutnya menurut Djamarah kata "media" berasal dari bahasa Latin dan merupakan bentuk jamak dari kata "medium", yang secara harfiah berarti "perantara atau pengantar". Dengan demikian, media merupakan wahana penyalur informasi belajar atau penyalur pesan (Djamara, 2013).

Media yang digunakan dalam proses pembelajaran sangatlah beragam, penggunaan media pembelajaran merupakan alat bantu komunikasi guru didalam menyampaikan pelajaran kepada peserta didik. Menurut Wina Sanjaya "Media audio visual adalah media yang mempunyai unsur suara dan unsur gambar yang bisa dilihat, misalnya video, slide, suara, dan sebagainya" (Wina, $2010: 172$ ).

Berdasarkan pendapat diatas dapat dipahami bahwa media audio visual merupakan sebuah alat komunikasi pembelajaran yang fungsinya membantu guru dalam menyampaikan isi pelajaran, media audio visual ini mempunyai dua unsur yaitu suara dan gambar seperti contoh: vidio, film, silde suara maupun vidio bergambar dan lainnya.

\section{1) Jenis Media Audio Visual}

Menurut Ernadia dalam jurnalnya menyebutkan bahwa jenis media audio visual dibagi menjadi dua jenis, yang pertama media audio visual murni, seperti film gerak (movie bersuara), televisi dan vidio. Adapaun yang kedua adalah media audio visual tidak murni, yaitu yang dikenal dengan slide dan peralatan lainnya, bila diberi unsur suara dari rekaman kaset yang dimanfaatkan secara bersamaan dalam satu waktu atau proses pembelajaran (Ernadia, 2019).

Selanjutnya dalam jurnal purnomo menyebutkan bahwa kedua jenis media audio visual pada umumnya digunakan untuk hiburan, dokumentasi dan pendidikan. Film dan video dapat menyajikan informasi, memaparkan proses, menjelaskan konsep-konsep yang rumit, mengajarkan keterampilan, menyingkat atau memperpanjang waktu, dan mempengaruhi sikap (Purnomo, 2014).

\section{2) Kelebihan Media Audio Visual}

Kelebihan media audio visual Menurut kutipan jurnal (Purnomo 2014) menyatakan bahwa media audio visual memiliki beberapa kelebihan atau kegunaan, antara lain: (1) memperjelas penyajian pesan agar tidak terlalu bersifat verbalistis (dalam bentuk katakata, tertulis atau lisan). (2) mengatasi keterbatasan ruang, waktu dan daya indera, seperti: objek yang terlalu besar digantikan dengan realitas, gambar, film bingkai, film atau model. (3) media audio-visual bisa berperan dalam pembelajaran tutorial.

Selanjutnya Sanjaya (2012:109) mengatakan tentang kelebihan dalam menggunakan media audio visual, yaitu: (1) dapat memeberikan pengalaman belajar yang tidak mungkin dipelajari secara langsung. (2) memungkinkan belajar lebih bervariatif sehingga dapat menambah motivasi dalam belajar. (3) dapat berfungsi sebagai sumber belajar secara mandiri tanpa sepenuhnya tergantung pada kehadiran guru (Sanjaya, 2012).

\section{3) Kekurangan Media Audio Visual}

Media audio visual juga memiliki kekurangan/kelemahan yaitu media audio visual terlalu menekankan pentingnya materi ketimbang proses pengembangan materi tersebut. Hal lain adalah pembuatan dan penggunaan media audio visual dalam proses pembelajaran terutama dinegara kita masih sangat minim (sedikit), hal ini karena media audio visual ini masih tergolong mahal atau memakan biaya yang tinggi (Yusra, 2019).

\section{4) Tujuan dan Manfaat Media Audio Visual}

Tujuan media audio visual Menurut jurnal Ayu Fitria mengutip pendapat Anderson (1994:102) mengemukakan beberapa tujuan dari pembelajaraan mengunakan media audio visual, antara lain: tujuan kognitif, tujuan afektif dan tujuan psikomotorik (Fitria, 2014). 
Mhd. Ricky Fadil Sihombing dan Alfurqan: Penggunaan Media Audio Visual dalam...

Manfaat media audio visual menurut (Miftahudin, 2016) manfaat dari media pembelajaran baik secara umum maupun khusus adalah sebagai alat bantu penyampaian isi pembelajaran bagi peserta didik. Adapun manfaat media pembelajaran audio visual sebagai berikut: (1) proses pembelajaran lebih menarik perhatian siswa sehingga dapat menumbuhkan motivasi belajar. (2) bahan/isi pembelajaran akan lebih jelas maknanya, sehingga dapat lebih difahami, serta siswa menguasai pelajaran dengan baik. (3) metode pembelajaran lebih beragam, tidak hanya komunikasi verbal melalui penuturan kata-kata lisan guru, siswa tidak bosan, dan guru tidak kehabisan tenaga. (4) Siswa lebih aktif melakukan kegiatan belajar, sebab tidak hanya mendengarkan penjelasan dari guru saja, tetapi melakukan aktivitas lain seperti: mengamati, melakukan, mendemonstrasikan, dan lain-lain.

\section{Metode}

Jenis Penelitian ini adalah penelitian lapangan (field research). Penelitian lapangan adalah penelitian yang dilakukan secara sistematis dengan mengangkat data yang ada di lapangan. Penelitian lapangan (field research) bertujuan untuk mengetahui gejala-gejala, melihat dan mengamati langsung situasi yang terjadi dilapangan (Sugiyono, 2012). Lokasi penelitian ini adalah di SDN 153028 Padang Masiang 1 yang berlokasi di Jalan Merdeka, Kelurahan Padang Masiang, Kecamatan Barus, Kabupaten Tapanuli Tengah.

Metode penelitian ini adalah metode kualitatif dengan pendekatan deskriptif. Menurut Sugiyono metode penelitian kualitatif dapat diartikan sebagai cara ilmiah untuk mendapatkan data yang valid dengan tujuan dapat ditemukan, dikembangkan, dan dibuktikan, suatu pengetahuan tertentu sehingga pada gilirannya dapat digunakan untuk memahami, memecahkan, dan mengantisipasi masalah dalam bidang pendidikan (Sugiyono, 2012).

Informan penelitian ini adalah orang yang merespon dan menjawab pertanyaan baik secara tertulis maupun lisan. Informan penelitian ini adalah siswa beragama Islam kelas IV, $\mathrm{V}$, dan VI sebanyak 22 siswa, guru Pendidikan Agama Islam (PAI) Ibu Badria Marpaung, S.Pd dan kepala sekolah 153028 Padang Masiang 1 Barus Kabupaten Tapanuli Tengah Bapak Basrul Harjah Sihotang, A.Ma.Pd.

Teknik Penelitian menggunakan teknik Purposive Sampling. Teknik Purposive Sampling adalah teknik pengambilan data dengan cara mempertimbangkan. Pertimbangan tertentu ini contohnya orang tersebut yang dianggap paling tahu tentang apa yang kita harapkan atau mungkin dia sebagai penguasa sehingga memudahkan peneliti menjelajahi objek atau situasi sosial yang diteliti (Sugiyono, 2012). Pengambilan data yang penulis ambil adalah siswa yang sudah mampu memahami tajwid, huruf dan kelancaran membaca Alquran (Fasoha).

Instrumen penelitian yang penulis gunakan dalam penelitian di SDN 153028 Padang Masiang 1 Barus Kabupaten Tapanuli Tengah adalah buku catatan dan handphone (sebagai alat rekam dan dokumentasi). Terkahir yang paling penting dalam penelitian ini adalah penulis sebagai instrumen penelitian yang langsung bertugas mengumpulkan data dilapangan, maksudnya adalah penulis sebagai instrumen yang secara langsung melaksanakan observasi dan wawancara dengan informan terkait permasalahan yang penulis teliti.

Teknik pengumpulan data merupakan langkah yang paling utama dalam penelitian, karena tujuan utama dalam penelitian adalah mendapatkan data yang memenehui standar data yang ditetapkan. Adapun data yang penulis peroleh dari penelitian ini, dikumpulkan dengan menggunakan metode sebagai berikut: Observasi, Wawancara dan Dokumentasi. Adapun analisis data yang penulis gunakan adalah: reduksi data, penyajian data dan penarikan kesimpulan. Uji keabsahan data dalam penelitian ini ditekankan pada uji validitas dan reliabilitas. Dalam penelitian kualitatif, temuan atau data dapat dinyatakan valid apabila tidak ada perbedaan antara yang dilaporkan penulis dengan apa yang sebenarnya terjadi pada objek yang diteliti. (Sugiyono, 2018). 


\section{Hasil dan Pembahasan}

\section{a. Penggunaan Media Pembelajaran Audio Visual dalam Meningkatkan Kemampuan Membaca Alquran.}

Penggunaan media pembelajaran audio visual dalam meningkatkan kemampuan membaca Alquran telah digunakan guru Pendidikan Agama Islam Ibu Badria Marpaung, S.Pd pada semester ganjil tahun pelajaran 2021/2022. Ibu Badria Marpaung, S.Pd memilih media audio visual jenis PowerPoint dan Vidio Rico The Series. Ibu Badria Marpaung, S.Pd mengajar menggunakan media audio visual ini sebagai informannya adalah pada kelas VI, V dan VI pada semester ganjil tahun pelajaran 2021/2022.

Dalam proses penelitian, penulis melihat dan mengamati proses pembelajaran Pendidikan Agama Islam pada materi Alquran Pada setiap kelas yang diajarkan Ibu Badria Marpaung, S.Pd. penulis mengamati jalannya proses pembelajaran dengan kegiatan pendahuluan, kegiatan inti dan kegiatan penutup pembelajaran. Sesuai dengan jadwal pembelajaran mata pelajaran Pendidikan Agama Islam yang telah ditetapkan.

Berdasarkan pelaksanaan pembelajaran menggunakan media audio visual maka diketahui media yang digunakan guru dalam proses pembelajaran yaitu media audio visual berbentuk slide power point dan penampilan video Rico The Series berjalan dengan baik.

\section{b. Faktor-Faktor Pendukung dan Penghambat dari Penggunaan Media Pembelajaran Audio Visual pada Materi Alquran.}

Berdasarkan hasil wawancara penulis dengan kepala sekolah Bapak Basrul Harjah, A.Ma.Pd dan guru Pendidikan Agama Islam Ibu Badria Marpaung, S.Pd, ditemukan beberapa faktor pendukung dan penghambat dari penggunaan media pembelajaran audio visual pada mata pelajaran Pendidikan Agama Islam materi Alquran.

\section{Faktor Pendukung:}

1) Bapak Basrul Harjah, A.Ma.Pd kepala sekolah SDN 153028 Padang Masiang 1 Barus Kabupaten Tapanuli Tengah telah memfasilitasi guru dalam menggunakan media pembelajaran audio visual.

2) Bapak Basrul Harjah, A.Ma.Pd. menyediakan proyektor infocus dan peralatan lainnya guna mempermudah guru dalam proses belajar mengajar dan menjadikan fasilitas tersebut sebagai sarana guru dalam menggunakan media audio visual pada mata pelajaran Pendidikan Agama Islam materi Alquran.

3) Kreatifitas dari Ibu Badria Marpaung, S.Pd. memilih media Slide PowerPoint dan menampilkan vidio Rico The Series sangat cocok digunakan dalam materi Alquran.

Faktor Penghambat

1) Guru Pendidikan Agama Islam Ibu Badria Marpaung, S.P.d sangat repot dalam mengangkat peralatan infocus, layar infokus tanpa adanya bantuan dari siswa.

2) Ibu Badria Marpaung, S.Pd. dituntut untuk lebih kreatif memilih vidio-vidio yang cocok untuk mendukung materi Alquran kepada siswa.

3) Ibu Badria Marpaung, S.Pd. susah dalam menentukan metode yang cocok dalam menggunakan media pembelajaran audio visual untuk mendukung materi Alquran kepada siswa.

c. Hasil dari Penggunaan Media Pembelajaran Audio Visual pada Materi Alquran.

Dari hasil penelitian yang telah penulis laksanakan disekolah SDN 153028 Padang Masiang 1 Barus, penulis memperoleh data dari ibu Badria Marpaung, S.Pd. sebelum menggunakan media audio visual dalam pembelajaran Pendidikan Agama Islam materi Alquran, yaitu hasil ulangan siswa pada semester genap tahun 2020/2021 pada tabel nilai berikut. 
Mhd. Ricky Fadil Sihombing dan Alfurqan: Penggunaan Media Audio Visual dalam...

Tabel 1.1. Hasil Ulangan Kelas III

Hasil Ulangan PAI Materi Alquran Kelas III T.P. 2020-2021/Semester Genap

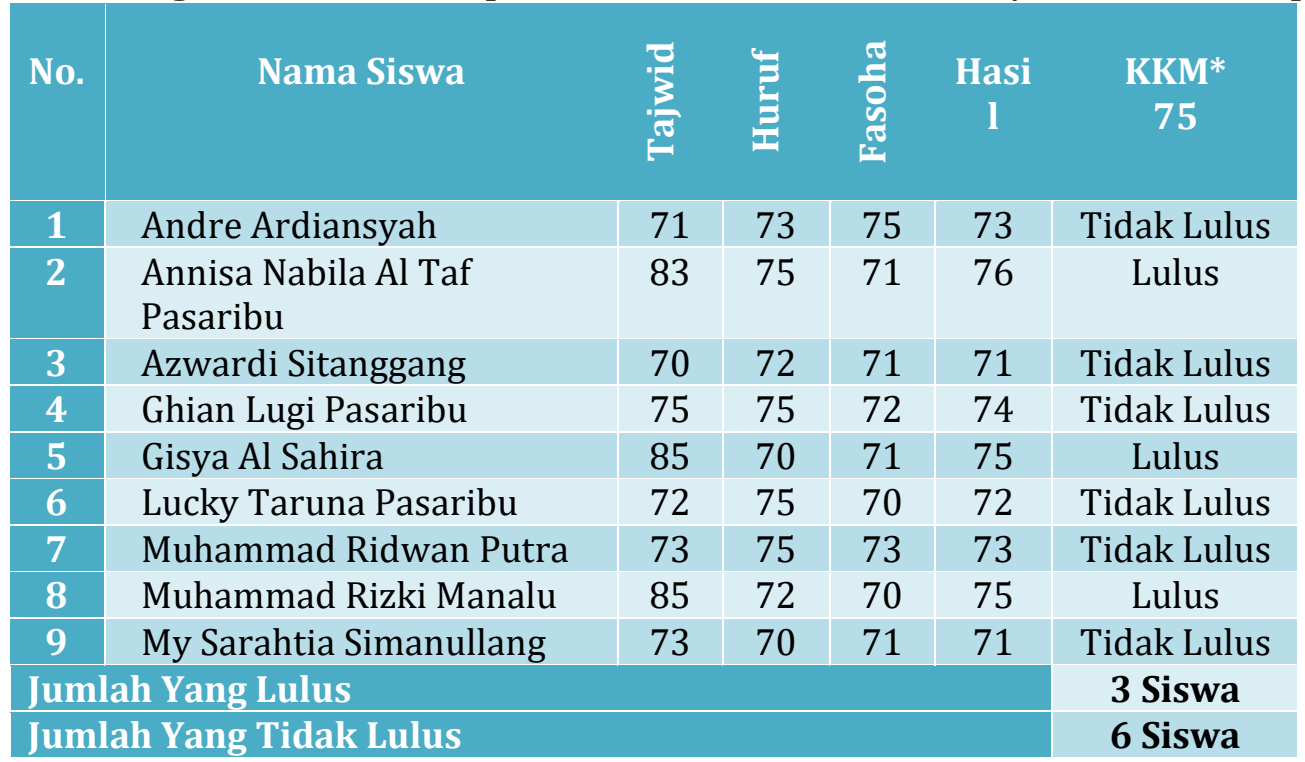

Sumber Data: Nilai Dari Guru PAI Tahun 2020/2021

Tabel 1.2. Hasil Ulangan Kelas IV

Hasil Ulangan PAI Materi Alquran Kelas IV T.P. 2020-2021/Semester Genap

\begin{tabular}{|c|c|c|c|c|c|c|}
\hline No. & Nama Siswa & $\frac{\sqrt[7]{3}}{\sqrt{\pi}}$ & 疍 & 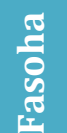 & Hasil & $\begin{array}{l}\mathrm{KKM}^{*} \\
75\end{array}$ \\
\hline 1 & Bisma Rafifa Meuraxa & 81 & 80 & 70 & 77 & Lulus \\
\hline 2 & Haryoga Marbun & 73 & 75 & 71 & 73 & Tidak Lulus \\
\hline 3 & Haslina Amanda Pasaribu & 80 & 73 & 73 & 75 & Lulus \\
\hline 4 & $\begin{array}{l}\text { Hanimawan Sari } \\
\text { Simanullang }\end{array}$ & 75 & 75 & 72 & 74 & Tidak Lulus \\
\hline 5 & $\begin{array}{l}\text { Muhammad Najwir } \\
\text { Marbun }\end{array}$ & 75 & 70 & 71 & 72 & Tidak Lulus \\
\hline 6 & Putri Nur Aini Pasaribu & 72 & 75 & 70 & 72 & Tidak Lulus \\
\hline \multicolumn{6}{|c|}{ Jumlah Yang Lulus } & 2 Siswa \\
\hline
\end{tabular}

Sumber Data: Nilai Dari Guru PAI Tahun 2020/2021

Tabel 1.3. Hasil Ulangan Kelas $V$

Hasil Ulangan PAI Materi Alquran Kelas V T.P. 2020-2021/Semester Genap

\begin{tabular}{|c|c|c|c|c|c|c|}
\hline No. & Nama Siswa & $\frac{\sqrt[3]{3}}{\sqrt[3]{\pi}}$ & 胥 & 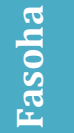 & Hasil & $\begin{array}{c}\mathrm{KKM}^{*} \\
\mathbf{7 5}\end{array}$ \\
\hline 1 & Annisa Tambunan & 71 & 70 & 70 & 70 & Tidak Lulus \\
\hline 2 & Dedek Olivia Sitanggang & 85 & 75 & 71 & 77 & Lulus \\
\hline 3 & Muhammad Arifin & 70 & 71 & 73 & 71 & Tidak Lulus \\
\hline 4 & Munawwar & 82 & 75 & 72 & 76 & Lulus \\
\hline 5 & Romi & 70 & 71 & 70 & 70 & Tidak Lulus \\
\hline
\end{tabular}




\begin{tabular}{|l|l|l|l|l|l|c|}
\hline 6 & Renol & 70 & 71 & 73 & 71 & Tidak Lulus \\
\hline 7 & Sahdi & 70 & 72 & 70 & 70 & Tidak Lulus \\
\hline Jumlah Yang Lulus & & & & & 2 Siswa \\
\hline Jumlah Yang Tidak Lulus & & & & & 5 Siswa \\
\hline
\end{tabular}

Sumber Data: Nilai Dari Guru PAI Tahun 2020/2021

\begin{tabular}{|l|c|}
\hline Keseluruhan Siswa Lulus & 7 Siswa \\
\hline Keseluruhan Siswa Tidak Lulus & 15 Siswa \\
\hline Total Keseluruhan Siswa & 22 Siswa \\
\hline
\end{tabular}

Dari hasil penelitian yang telah penulis laksanakan, penulis mendapatkan data dari Ibu Badria Marpaung, S.Pd. yang telah menggunakan media audio visual sebagai alat pendukung dalam meningkatkan kemampuan membaca Alquran di kelas VI, V dan VI Tahun 20212022/Semester Ganjil. Data yang penulis maksud adalah hasil ulangan Pendidikan Agama Islam pada materi Alquran pada tabel berikut:

Tabel 2.1. Hasil Ulangan Kelas IV

Hasil Ulangan PAI Materi Alquran Kelas IV T.P. 2021-2022/Semester Ganjil

\begin{tabular}{|c|c|c|c|c|c|c|}
\hline No. & Nama Siswa & $\frac{\sqrt{3}}{\frac{3}{\pi}}$ & 롤 & 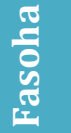 & Hasil & $\begin{array}{c}\mathrm{KKM}^{*} \\
75\end{array}$ \\
\hline 1 & Andre Ardiansyah & 83 & 75 & 71 & 76 & Lulus \\
\hline 2 & Annisa Nabila Al Taf Pasaribu & 81 & 80 & 75 & 78 & Lulus \\
\hline 3 & Azwardi Sitanggang & 75 & 81 & 73 & 76 & Lulus \\
\hline 4 & Ghian Lugi Pasaribu & 73 & 71 & 76 & 73 & Tidak Lulus \\
\hline 5 & Gisya Al Sahira & 85 & 70 & 71 & 75 & Lulus \\
\hline 6 & Lucky Taruna Pasaribu & 81 & 75 & 73 & 76 & Lulus \\
\hline 7 & Muhammad Ridwan Putra & 70 & 72 & 75 & 72 & Tidak Lulus \\
\hline 8 & Muhammad Rizki Manalu & 85 & 72 & 70 & 75 & Lulus \\
\hline 9 & My Sarahtia Simanullang & 75 & 80 & 76 & 77 & Lulus \\
\hline \multicolumn{6}{|c|}{ Jumlah Yang lulus } & 7 Siswa \\
\hline \multicolumn{6}{|c|}{ Jumlah Yang Tidak Lulus } & 2 Siswa \\
\hline
\end{tabular}

Sumber Data: Nilai Dari Guru PAI Tahun 2021/2022

Tabel 2.2. Hasil Ulangan Kelas $\mathrm{V}$

Hasil Ulangan PAI Materi Alquran Kelas V T.P. 2021-2022/ Semester Ganjil

\begin{tabular}{|c|c|c|c|c|c|c|}
\hline No. & Nama Siswa & $\frac{\sqrt{3}}{\sqrt{\pi}}$ & 胥 & 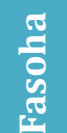 & Hasil & $\begin{array}{l}\mathrm{KKM}^{*} \\
\mathbf{7 5}\end{array}$ \\
\hline 1 & Bisma Rafifa Meuraxa & 83 & 81 & 72 & 78 & Lulus \\
\hline 2 & Haryoga Marbun & 72 & 75 & 73 & 73 & Tidak Lulus \\
\hline 3 & Haslina Amanda Pasaribu & 85 & 80 & 73 & 79 & Lulus \\
\hline 4 & $\begin{array}{l}\text { Hanimawan Sari } \\
\text { Simanullang }\end{array}$ & 83 & 82 & 70 & 78 & Lulus \\
\hline 5 & $\begin{array}{l}\text { Muhammad Najwir } \\
\text { Marbun }\end{array}$ & 80 & 82 & 73 & 78 & Lulus \\
\hline 6 & Putri Nur Aini Pasaribu & 81 & 70 & 72 & 74 & Tidak Lulus \\
\hline
\end{tabular}


Mhd. Ricky Fadil Sihombing dan Alfurqan: Penggunaan Media Audio Visual dalam...

\begin{tabular}{|l|l}
\hline Jumlah Yang lulus & 4 Siswa \\
\hline Jumlah Yang Tidak Lulus & 2 Siswa
\end{tabular}

Sumber Data: Nilai Dari Guru PAI Tahun 2021/2022

Tabel 2.3. Hasil Ulangan Kelas VI

Hasil Ulangan PAI Materi Alquran Kelas VI T.P. 2021-2022/ Semester Ganjil

\begin{tabular}{|c|c|c|c|c|c|c|}
\hline No. & Nama Siswa & 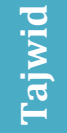 & E & 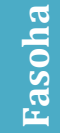 & Hasil & $\begin{array}{c}\mathrm{KKM}^{*} \\
\mathbf{7 5}\end{array}$ \\
\hline 1 & Annisa Tambunan & 80 & 72 & 73 & 75 & Lulus \\
\hline 2 & Dedek Olivia Sitanggang & 82 & 80 & 73 & 78 & Lulus \\
\hline 3 & Muhammad Arifin & 73 & 75 & 70 & 72 & Tidak Lulus \\
\hline 4 & Munawwar & 82 & 75 & 72 & 76 & Lulus \\
\hline 5 & Romi & 81 & 70 & 73 & 74 & Tidak Lulus \\
\hline 6 & Renol & 82 & 75 & 81 & 79 & Lulus \\
\hline 7 & Sahdi & 81 & 73 & 75 & 76 & Lulus \\
\hline \multicolumn{6}{|c|}{ Jumlah Yang lulus } & 5 Siswa \\
\hline \multicolumn{6}{|c|}{ Jumlah Yang Tidak Lulus } & 2 Siswa \\
\hline
\end{tabular}

Sumber Data: Nilai Dari Guru PAI Tahun 2021/2022

\begin{tabular}{|l|c|}
\hline Keseluruhan Siswa Lulus & 16 Siswa \\
\hline Keseluruhan Siswa Tidak Lulus & 6 Siswa \\
\hline Total Keseluruhan Siswa & 22 Siswa \\
\hline
\end{tabular}

Berdasarkan hasil penelitian yang telah penulis paparkan di atas, maka dapat diketahui bahwa Penggunaan Media Pembelajaran Audio Visual Dalam Meningkatkan Kemampuan Membaca Alquran Di SDN 153028 Padang Masiang 1 Barus Kabupaten Tapanuli Tengah berjalan dengan lancar dan dilihat dari nilai ulangan materi Alquran siswa dari kelas IV, $\mathrm{V}$ dan VI setelah diterapkan media pembelajaran audio visual ini, nilai siswa tersebut meningkat dan siswa mempraktikkan bacaannya sudah banyak peningkatan dan sudah mampu membaca Alquran dengan benar.

Dari data hasil ulangan Pendidikan Agama Islam pada materi Alquran yang telah penulis peroleh dari Ibu Badria Marpaung, S.Pd tersebut, diketahui bahwa hasil ulangan siswa menunjukkan 7 orang siswa yang lulus dan sebanyak 15 orang siswa belum mampu membaca Alquran dengan baik dilihat dari kategori tajwid, huruf dan fasoha yang belum mencapai KKM. Data ini merupakan hasil dari proses pembelajaran guru Pendidikan Agama Islam T.P. 2020-2021/Semester Genap yang belum menggunakan media pendukung pembelajaran Pendidikan Agama Islam pada materi Alquran.

Dari data hasil ulangan Pendidikan Agama Islam pada materi Alquran yang telah penulis peroleh dari Ibu Badria Marpaung, S.Pd tersebut, diketahui bahwa hasil ulangan siswa menunjukkan 16 orang siswa yang sudah lulus kategori tajwid, huruf dan fasoha yang telah mencapai KKM serta sebanyak 6 orang siswa belum lulus.

Data ini merupakan hasil dari proses pembelajaran yang dilaksanakan oleh Ibu Badria Marpaung, S.Pd. selaku guru Pendidikan Agama Islam T.P. 2021-2022/Semester Ganjil yang telah menggunakan media audio visual sebagai alat pendukung dalam meningkatkan kemampuan membaca Alquran di SDN 153028 Padang Masiang 1 Barus.

Selanjutnya pengambilan sampel untuk penelitian menurut Suharsimi Arikunto (2010), Sampel adalah sebagian atau wakil dari populasi yang akan diteliti. jika subjek nya kurang dari 100 orang sebaiknya diambil semuanya, jika subjeknya besar atau lebih dari 100 orang dapat di ambil 10-15\% atau 20-25\% atau lebih (Arikunto, 2010). Berdasarkan teori ini 
bahwa sampel yang ada pada penelitian ini berjumlah 22 siswa yang terdiri dari 3 kelas yaitu kelas IV, V dan VI. Maka sesuai teori Suharsimi Arikunto ini sampel dalam penelitian ini dapat di ambil semuanya untuk dijadikan sampel dalam penelitian ini.

Tabel 3. Jadwal Belajar Siswa

\begin{tabular}{|c|c|c|c|}
\hline Kelas & Jumlah Siswa & Jadwal & $\begin{array}{l}\text { Alokasi } \\
\text { Waktu }\end{array}$ \\
\hline IV & 9 Orang & $\begin{array}{c}\text { Senin, } \\
\text { Jam 07.00 - 08.30 WIB }\end{array}$ & $3 \mathrm{JP}$ \\
\hline V & 6 Orang & $\begin{array}{c}\text { Rabu, } \\
\text { Jam 07.00 - 08.30 WIB }\end{array}$ & $3 \mathrm{JP}$ \\
\hline VI & 7 Orang & $\begin{array}{c}\text { Jum'at, } \\
\text { Jam 07.00 - 08.30 WIB }\end{array}$ & $3 \mathrm{JP}$ \\
\hline
\end{tabular}

Sumber Data: Guru PAI T.P. 2021/2022

Dalam tabel jadwal belajar siswa diatas dapat diketahui bahwa kelas yang digunakan guru media audio visual dalam pembelajaran Pendidikan Agama Islam pada materi Alquran ada tiga kelas yaitu kelas IV pada hari Senin, V pada hari Rabu dan VI pada hari Jum'at. Kemudian Ibu Badria Marpaung, S.Pd memberikan 3 Jam Pelajaran setiap minggunya yaitu 1 jam pelajaran sekitar 30 menit atau 3x 30 sekitar 1 jam 30 menit.

Berdasarkan dari hasil penelitian yang telah penulis teliti dan pahami akhirnya pembelajran menggunakan media audio visual sebagai alat pendukung dalam meningkatkan kemampuan membaca Alquran, penulis menilai bahwa terdapat peningkatan yang signifikan pada siswa kelas IV, V dan VI SDN 153028 Padang Masiang 1 Barus Kabupaten Tapanuli Tengah, dilihat dari hasil nilai ulangan materi Alquran siswa yang meningkat serta pembacaan Alquran setiap siswa sudah ada perubahan yang lebih baik.

\section{Simpulan}

Penggunaan media pembelajaran audio visual dalam meningkatkan kemampuan membaca Alquran Di SDN 153028 Padang Masiang 1 Barus Kabupaten Tapanuli Tengah. Setelah penulis melihat dan mengamati proses pembelajaran Pendidikan Agama Islam dalam materi Alquran menggunakan media audio visual, siswa sangat antusias dalam belajar dan siswa lebih aktif bertanya dan mempraktikkan bacaan Alquran.

Hasil dari penggunaan media pembelajaran audio visual dalam meningkatkan kemampuan membaca Alquran Di SDN 153028 Padang Masiang 1 Barus Kabupaten Tapanuli Tengah, penulis menemukan nilai ulangan materi Alquran siswa T.P. 2020/2021 Semester Genap yang tidak lulus KKM 75 berjumlah 15 siswa dan yang lulus berjumlah 7 siswa. Selanjutnya setelah guru Ibu Badria Marpaung, S.Pd menggunakan media pembelajaran audio visual pada T.P. 2021/2022 Semester Ganjil, nilai ulangan materi Alquran siswa telah lulus KKM 75 sebanyak 16 siswa dan yang tidak lulus KKM 75 sebanyak 6 siswa.

Berdasarkan rangkuman kesimpulan diatas, penulis menyimpulkan bahwa penggunaan media media pembelajaran audio visual dalam meningkatkan kemampuan membaca Alquran Di SDN 153028 Padang Masiang 1 Barus Kabupaten Tapanuli Tengah telah mengalami peningkatan yang signifikan dalam proses pembelajaran siswa sangat antusisas belajar membaca Alquran dan perubahan nilai siswa yang meningkat serta siswa sudah mampu membaca Alquran dengan baik dan benar sesuai kategori Tajwid, Makharijul Huruf dan Fasoha (Kelancaran).

\section{Referensi}

Arikunto, Suharsimi. 2010. Prosedur Penelitian Suatu Pendekatan Praktek. Jakarta: Rineka 
Mhd. Ricky Fadil Sihombing dan Alfurqan: Penggunaan Media Audio Visual dalam...

Cipta.

Arsyad, Azhar. 2011. Media Pembelajaran. Jakarta: PT.Rajagrafindo Persada.

Arsyad, Azhar. 2013. Media Pembelajaran. 13th ed. Jakarta: PT.Raja Grafindo Persada.

Djamara, Zain. 2013. Starategi Belajar Mengajar. Jakarta: Rineka Cipta.

Ernadia. 2019. "Media Audio Visual Dalam Pembelajaran PAI." Pendidikan Islam 2:111.

Fitria, Ayu. 2014. "Penggunaan Media Audio Visual Dalam Menunjang Pembelajaran." Pendidikan 05(02):1-8.

Hastuti, Ari, and Yudi Budianti. 2014. "Pengaruh Penggunaan Media Audio Visual Terhadap Hasil Belajar Siswa Pada Mata Pelajaran Ipa Kelas Ii Sdn Bantargebang Ii Kota Bekasi." Jurnal Pedagogik 2(2):33-38.

Miftahudin. 2016. "Skripsi Pengaruh Penggunaan Media Audio Visual Terhadap Kemampuan Membaca Al-Qur' An Kabupaten Lampung Tengah Oleh: Miftahudin Sekolah Tinggi Agama Islam Negeri (STAIN) Jurai Siwo Metro Tahun 1437 H / 2016 M.”

Purnomo, Joni. 2014. "Penggunaan Media Audio-Visual Pada Mata Pelajaran Ilmu Pengetahuan Alam Di Sekolah Menengah Pertama Negeri." Jurnal Teknologi Pendidikan Dan Pembelajaran 2(2):127-44.

Raco, J. R. 2010. Metode Penelitian Kualitatif “Jenis, Karakteristik Dan Keunggulannya." Jakarta: Kompas Gramedia.

Rahmawati, Ussi. 2014. "Media Audio Visual Dalam Pembelajaran Alquran Hadits Di MI Ma'arif NU 1 Rancamaya Kecamatan Cilongok Kabupaten Banyumas.” IAIN Purwokerto, Pureokerto.

Rama joni, Abdul Rahman, Eka Yanuarti. 2020. "Strategi Guru Agama Desa Dalam Meningkatkan Kemampuan Membaca Al-Quran Warga Desa." Journal of Education and Instruction 03(01):1689-99.

Sanjaya. 2012. Starategi Pembelajaran Berorientasi Standar Proses Pendidikan. Jakarta: Kencana Prenada Media Grup.

Shihab, Quraish. 2008. Sejarah Dan Ulum Al-Qur'an. Jakarta: Pusataka Firdaus.

Sugiyono. 2012. Metode Penelitian Kuantitatif, Kualitatif Dan R\&D. Bandung: Alfabeta.

Sugiyono. 2018. Metode Penelitian Kuantitatif, Kualitatif Dan R\&D. Bandung: Alfabeta.

Suyanto, Djihad Hisyam. 2010. Pendidikan Indonesia Memasuki Milenium III. Yogyakarta: Adicita Karya Nusa.

Syaifullah, Muhammad. 2017. "Penerapan Metode An-Nahdliyah Dan Metode Iqro Dalam Kemampuan Membaca Alquran." Jurnal Kajian Ilmu Pendidikan 2:146.

Wina, Sanjaya. 2010. Strategi Pembelajaran Berorientasi Standar Proses Pendidikan. Jakarta: Kencana.

Yusra, Rizki Al. 2019. “Media Audio Visual Dalam Pembelajaran PAI.” 2(1):101-12. 